Portland State University

PDXScholar

3-12-2021

\title{
How to Effectively Manage Virtual Teams Created Due to COVID-19?
}

Aakanksha Santosh Rane

Portland State University

Follow this and additional works at: https://pdxscholar.library.pdx.edu/honorstheses

Part of the Human Resources Management Commons, Leadership Studies Commons, and the Organizational Communication Commons Let us know how access to this document benefits you.

\section{Recommended Citation}

Rane, Aakanksha Santosh, "How to Effectively Manage Virtual Teams Created Due to COVID-19?" (2021). University Honors Theses. Paper 982.

https://doi.org/10.15760/honors.1006

This Thesis is brought to you for free and open access. It has been accepted for inclusion in University Honors Theses by an authorized administrator of PDXScholar. Please contact us if we can make this document more accessible: pdxscholar@pdx.edu. 


\title{
How to effectively manage virtual teams created due to COVID-19?
}

\begin{abstract}
:
With the spread of COVID-19 and the social distancing regulations in place, multiple organizations have transitioned their workplace to a virtual setting. With the increase in business' transitioning to remote teams, it is first crucial to understand the various needs and characteristics of virtual teams. Through the analysis of multiple peer-reviewed articles and other texts on virtual teams, this study identifies building trust, effective communication, and performance management as the main points of focus in order to ensure effectiveness of virtual teams.
\end{abstract}

Keywords: virtual teams, COVID-19, virtual team leadership, virtual team management.

\section{Background:}

In early January, the World Health Organization (WHO) publicly acknowledged the spread of the coronavirus or COVID-19 and after a number of cases in America and the announcement of a global pandemic, on March 13, 2020, President Trump declared a national emergency, and also announced the close of cooperation with private sector leaders (Myers, 2020). This led to a number of businesses in the private sector to create virtual workspaces for their non-essential employees and the need for virtual teams has created a huge change in how companies manage and lead their employees. As organizations experience this transition, this research aims to act as a resource for current leaders by identifying the various factors that contribute to the success of virtual teams.

\section{Understanding Virtual Teams:}

Virtual teams are teams in which multiple members are situated in different geographical locations and are dependent highly on the use of technology for inter-member communication (Townsend et al., 1998). In most cases virtual teams are set up by the organization to solve key issues such as: constructing an ideal range of human resources to encourage cross-boundary collaboration (Ebrahim et al., 2009) and building teams that can address location-specific needs (Ford et al., 2017).

However, this pandemic and the need for organizations to create work environments that are physically safe for their workforce has increased the demand for virtual workspaces that have forced employees to work from home. According to data collected through a survey conducted in May of 2020 that focused on understanding how COVID-19 has impacted the US workforce, it was found that about $35.2 \%$ of workers had to switch to working from home due to the pandemic (Brynjolfsson et al., 2020). In addition to that, it was found that $15 \%$ were already working remotely before the pandemic therefore, indicating that about half of the overall US workforce is now working remotely (Brynjolfsson et al., 2020).

With the increase in organizations transitioning to remote teams, it is first crucial to understand the key characteristics of virtual teams. Firstly, one of the key indicators of a virtual team is the geographic dispersion of team members (Wong \& Burton, 2000). The extent of geographic dispersion can vary widely from having one member located in a different location than the rest of the team to extreme dispersion where each member is located in a different country (Ebrahim et al., 2009). Many organizations find this to be highly beneficial as it allows them to access and 
recruit individuals who are best fit for the job without experiencing restrictions due to location (Ebrahim et al., 2009). Secondly, virtual teams are dependent mainly on technology as the primary form of communication (Brandt et al., 2011). Finally, each member of the team is driven by one common purpose (Ebrahim et al., 2009). This means they all work together to achieve the goals of the overall team.

\section{Issues that arise with Virtual teams:}

Despite all the benefits associated with virtual teams, when looking at the larger picture they are highly complex to navigate. The locational (the physical separation of team members), temporal (differences in lifestyle and synchronicity of team members) and relational (disparities in relational network of each team member) boundaries pose as a threat to the levels of productivity, team dynamic, and the overall success of the team (Martins et al., 2004). Firstly, these boundaries make it challenging for managers to effectively manage and navigate conflict that may arise within the team (Kankanhalli et al., 2014). The limited interactions and physical dispersion of team members make it difficult for managers to monitor and control overall team activities (Powell et al., 2004). In addition to that, the high levels of dependence on technology for all team communication increases costs as organizations have to invest time researching and identifying the appropriate task technology fit, the appropriate technology tools needed, as well as providing training to their employees on how to use them in order to ensure that the team can manage their operations successfully (Townsend et al., 1998).

Overall, limited interactions among team members due to the physical barriers makes virtual teams more vulnerable to high levels of mistrust among team members. It is often found that the numerous informal interactions that take place in a physical workplace can help build social ties among team members which can have a positive effect on their interpersonal relations (Siebdrat et al., 2009). This is lost when dealing with virtual teams as member interactions and communication are very limited and, in most cases, strictly work related. Furthermore, the inability to easily monitor and control team activities, team leaders may have to reinforce all processes in a very formal and structured manner (Ford et al., 2017). This in turn may result in team members feeling as though they do not have much control over their work and therefore negatively impact their levels of trust with their managers and team leads. Finally, through the separation, the team may develop certain levels of cultural and work process diversity which in turn may lead to disparities in members' thought processes (Shachaf, 2008). Overall, all of this will negatively impact team collaboration which in turn could damage the levels of trust among team members.

Virtual teams that are created due to COVID-19 are highly unique from previous virtual teams. Firstly, they may not experience a lot of issues with location, such as time zone differences, due to the fact that may be located in the same region as they were working in-person before the pandemic. In addition to that, most teams may not consist of a lot of cross-boundary collaboration unlike virtual teams set up before the pandemic as they were not created for specific projects but rather to continue their regular departmental work in a virtual setting. However, current virtual teams may experience communication as the biggest challenge as it will be different from what they are used to.

It is therefore evident that managing large teams virtually can be challenging. This pandemic has pushed a number of organizations in a complex environment as they experience a sudden shift to the virtual world and have forced their employees to navigate and deal with the loss of 
in-person interactions that helped support their social needs. Based on the research I have conducted, my goal in this article is to provide a resource for current managers and leaders on how they can navigate the virtual workplace and create practices that best support their employees to create a positive impact on their overall performance and success.

\section{Methods:}

This paper reviews and highlights the key takeaways on virtual teams from quantitative and qualitative data that currently exists. To find literature that aligns with this topic I began by look at peer-reviewed articles on various databases and search engines such as Google Scholar, Business Source Premier, and Science Direct. During my data search and collection process, I used key search words and phrases, on these various databases, such as virtual teams, virtual team leadership, managing virtual teams, and global virtual teams. I started the data collection process in October 2020 and after I reviewed through each article, I identified some key findings and similarities among them. As a reference source, I created a summary table (Table 1) that looks at the various articles that are a part of my literature review and their key findings:

Table 1:

\begin{tabular}{|l|l|l|l|}
\hline Authors & Title & Date & Findings \\
\hline $\begin{array}{l}\text { Huang, W. W., Wei, } \\
\text { T., \& Tan, B. C. Y. }\end{array}$ & $\begin{array}{l}\text { Supporting virtual } \\
\text { team building with a } \\
\text { GSS: An empirical } \\
\text { investigation }\end{array}$ & 2003 & $\begin{array}{l}\text { Goal-setting structure increased team } \\
\text { cohesion, commitment, and } \\
\text { collaboration within virtual teams. }\end{array}$ \\
\hline $\begin{array}{l}\text { Dube Shopee \& } \\
\text { Marnewick Carl. }\end{array}$ & $\begin{array}{l}\text { A conceptual model } \\
\text { to improve } \\
\text { performance in } \\
\text { virtual teams: } \\
\text { Original research }\end{array}$ & 2016 & $\begin{array}{l}\text { Performance criteria for the virtual } \\
\text { teams: leadership, trust, } \\
\text { communication, team cooperation, } \\
\text { reliability, motivation, comfort and } \\
\text { social interaction. }\end{array}$ \\
\hline $\begin{array}{l}\text { Forester, G. L., } \\
\text { Thorns, P., \& Pinto, } \\
\text { J. K. }\end{array}$ & $\begin{array}{l}\text { Importance of Goal } \\
\text { Setting in Virtual } \\
\text { Project Teams }\end{array}$ & 2007 & $\begin{array}{l}\text { Survey collected data suggests } \\
\text { managers can improve outcomes } \\
\text { using strategies of goal theory. }\end{array}$ \\
\hline $\begin{array}{l}\text { Hertel, G., Geister, } \\
\text { S., \& Konradt, U. }\end{array}$ & $\begin{array}{l}\text { Managing virtual } \\
\text { teams: } \text { A review of } \\
\text { current empirical } \\
\text { research }\end{array}$ & 2005 & $\begin{array}{l}\text { Strong need for clarified team goals } \\
\text { and roles, implementation of efficient } \\
\text { communication tools, continuous } \\
\text { support of team awareness and } \\
\text { informal communication, constant } \\
\text { feedback, and creating } \\
\text { interdependence. }\end{array}$ \\
\hline $\begin{array}{l}\text { Susanne Geister, } \\
\text { Udo Konradt, \& }\end{array}$ & $\begin{array}{l}\text { Guido Hertel. } \\
\text { Feedback on } \\
\text { Motivation, } \\
\text { Satisfaction, and } \\
\text { Performance in } \\
\text { Virtual Teams. }\end{array}$ & 2006 & $\begin{array}{l}\text { A study on 52 virtual teams suggests } \\
\text { feedback improves levels of } \\
\text { motivation, interpersonal trust, } \\
\text { performance, and satisfaction. }\end{array}$ \\
\hline
\end{tabular}




\begin{tabular}{|c|c|c|c|}
\hline $\begin{array}{l}\text { Wakefield, R. L., } \\
\text { Leidner, D. E., \& } \\
\text { Garrison, G }\end{array}$ & $\begin{array}{l}\text { A Model of Conflict, } \\
\text { Leadership, and } \\
\text { Performance in } \\
\text { Virtual Teams. }\end{array}$ & 2008 & $\begin{array}{l}\text { Survey collected data suggests } \\
\text { communication technologies and } \\
\text { team roles can reduce task conflict. }\end{array}$ \\
\hline $\begin{array}{l}\text { Lurey, J. S., \& } \\
\text { Raisinghani, M. S. }\end{array}$ & $\begin{array}{l}\text { An empirical study } \\
\text { of best practices in } \\
\text { virtual teams. } \\
\text { Information \& } \\
\text { Management. }\end{array}$ & 2001 & $\begin{array}{l}\text { Study on } 12 \text { virtual teams suggests } \\
\text { that teams' processes and team } \\
\text { members' relations has a strong } \\
\text { positive impact on team performance } \\
\text { and satisfaction. }\end{array}$ \\
\hline $\begin{array}{l}\text { Ford, R. C., Piccolo, } \\
\text { R. F., \& Ford, L. R. }\end{array}$ & $\begin{array}{l}\text { Strategies for } \\
\text { building effective } \\
\text { virtual teams: Trust } \\
\text { is key. }\end{array}$ & 2017 & $\begin{array}{l}\text { Various strategy contributes to } \\
\text { building and sustaining a climate of } \\
\text { trust in virtual teams. }\end{array}$ \\
\hline $\begin{array}{l}\text { Powell, A., Piccoli, } \\
\text { G., \& Ives }\end{array}$ & $\begin{array}{l}\text { Virtual teams: } A \\
\text { review of current } \\
\text { literature and } \\
\text { directions for future } \\
\text { research }\end{array}$ & 2004 & $\begin{array}{l}\text { The article presented a } \\
\text { comprehensive list of issues that have } \\
\text { been examined by virtual team } \\
\text { research to date. }\end{array}$ \\
\hline Shachaf, P. & $\begin{array}{l}\text { Cultural diversity } \\
\text { and information and } \\
\text { communication } \\
\text { technology impacts } \\
\text { on global virtual } \\
\text { teams: An } \\
\text { exploratory study }\end{array}$ & 2008 & $\begin{array}{l}\text { An interview with } 41 \text { team members } \\
\text { highlighted the understanding of } \\
\text { cultural diversity and technology on } \\
\text { team effectiveness. }\end{array}$ \\
\hline $\begin{array}{l}\text { Hill, N. S., \& } \\
\text { Bartol, K. M. }\end{array}$ & $\begin{array}{l}\text { Five Ways to } \\
\text { Improve } \\
\text { Communication in } \\
\text { Virtual Teams }\end{array}$ & 2018 & $\begin{array}{l}\text { Peer assessments focused on five best } \\
\text { practices: finding task and technology } \\
\text { fit, ensuring clear intentions, staying } \\
\text { connected, being receptive and } \\
\text { supportive, and being accessible and } \\
\text { inclusive. }\end{array}$ \\
\hline $\begin{array}{l}\text { Hoch, J. E., \& } \\
\text { Dulebohn, J. H. }\end{array}$ & $\begin{array}{l}\text { Team personality } \\
\text { composition, } \\
\text { emergent leadership } \\
\text { and shared } \\
\text { leadership in virtual } \\
\text { teams: A theoretical } \\
\text { framework. }\end{array}$ & 2017 & $\begin{array}{l}\text { The article proposes a virtual team } \\
\text { structure that presents the team } \\
\text { personality composition as predictors } \\
\text { of emergent and shared leadership. }\end{array}$ \\
\hline $\begin{array}{l}\text { Wong, S.-S., \& } \\
\text { Burton, R. M. }\end{array}$ & $\begin{array}{l}\text { Virtual Teams: } \\
\text { What are their } \\
\text { Characteristics, and } \\
\text { Impact on Team } \\
\text { Performance? }\end{array}$ & 2000 & $\begin{array}{l}\text { Based on these results, strategies to } \\
\text { improve performance include } \\
\text { increasing the ease of communication, } \\
\text { clarifying role expectations, and } \\
\text { implementing a lateral structure. }\end{array}$ \\
\hline
\end{tabular}




\begin{tabular}{|c|c|c|c|}
\hline $\begin{array}{l}\text { Virginia Brandt, } \\
\text { William England, \& } \\
\text { Susan Ward. }\end{array}$ & Virtual Teams. & 2011 & $\begin{array}{l}\text { Highlights how team functions such } \\
\text { as trust, cultural differences, } \\
\text { communication, social skills, and } \\
\text { mission and goal clarity makes virtual } \\
\text { teams different from teams that meet } \\
\text { in person. }\end{array}$ \\
\hline $\begin{array}{l}\text { Clark, W. R., Clark, } \\
\text { L. A., \& Crossley, } \\
\text { K. }\end{array}$ & $\begin{array}{l}\text { Developing } \\
\text { Multidimensional } \\
\text { Trust Without Touch } \\
\text { In Virtual Teams. }\end{array}$ & 2010 & $\begin{array}{l}\text { Results suggest that focusing on the } \\
\text { three dimensions of trust, can help } \\
\text { create a more friendly environment } \\
\text { for trust development without face-to- } \\
\text { face interactions. }\end{array}$ \\
\hline $\begin{array}{l}\text { Robert, L. P., \& } \\
\text { You, S. }\end{array}$ & $\begin{array}{l}\text { Are you satisfied } \\
\text { yet? Shared } \\
\text { leadership, } \\
\text { individual trust, } \\
\text { autonomy, and } \\
\text { satisfaction in } \\
\text { virtual teams }\end{array}$ & 2018 & $\begin{array}{l}\text { A study on } 44 \text { virtual teams indicated } \\
\text { that shared leadership supports } \\
\text { satisfaction in virtual teams as it } \\
\text { encourages trust. }\end{array}$ \\
\hline $\begin{array}{l}\text { Eva C. Kasper- } \\
\text { Fuehrera \& Neal M. } \\
\text { Ashkanasy. }\end{array}$ & $\begin{array}{l}\text { Communicating } \\
\text { trustworthiness and } \\
\text { building trust in } \\
\text { interorganizational } \\
\text { virtual } \\
\text { organizations }\end{array}$ & 2001 & $\begin{array}{l}\text { Results suggest that communication } \\
\text { of trustworthiness assisted by } \\
\text { consistent Communication } \\
\text { Technology creates a common } \\
\text { business understanding, and strong } \\
\text { business ethics. }\end{array}$ \\
\hline $\begin{array}{l}\text { Atreyi Kankanhalli, } \\
\text { Bernard C.Y. Tan, } \\
\text { \& Kwok-Kee Wei. }\end{array}$ & $\begin{array}{l}\text { Conflict and } \\
\text { Performance in } \\
\text { Global Virtual } \\
\text { Teams }\end{array}$ & 2014 & $\begin{array}{l}\text { Results suggest that managers should } \\
\text { be aware of the potential conflicts } \\
\text { resulting from team diversity, } \\
\text { communication technology effects on } \\
\text { conflict, relationship between conflict } \\
\text { attribution and conflict resolution } \\
\text { approaches. }\end{array}$ \\
\hline $\begin{array}{l}\text { Newman, S. A., \& } \\
\text { Ford, R. C. }\end{array}$ & $\begin{array}{l}\text { Five Steps to } \\
\text { Leading Your Team } \\
\text { in the Virtual } \\
\text { COVID-19 } \\
\text { Workplace. } \\
\text { Organizational } \\
\text { Dynamics }\end{array}$ & 2020 & $\begin{array}{l}\text { This article suggests the need to } \\
\text { establish the new reality, a culture of } \\
\text { trust, leadership communication tools } \\
\text { and technique, shared leadership } \\
\text { among team members, alignment } \\
\text { audits to ensure that the team aligns } \\
\text { with the organization culture and } \\
\text { values. }\end{array}$ \\
\hline $\begin{array}{l}\text { Kanawattanachai, } \\
\text { P., \& Yoo, Y. }\end{array}$ & $\begin{array}{l}\text { Dynamic nature of } \\
\text { trust in virtual } \\
\text { teams. }\end{array}$ & 2002 & $\begin{array}{l}\text { Results from studying } 36 \text { teams found } \\
\text { that both high- and low-performing } \\
\text { teams began with the same levels of } \\
\text { trust however, high-performing teams } \\
\text { were better at building and retaining } \\
\text { the trust level. }\end{array}$ \\
\hline
\end{tabular}




\begin{tabular}{|c|c|c|c|}
\hline $\begin{array}{l}\text { Marlow, S. L., } \\
\text { Lacerenza, C. N., \& } \\
\text { Salas, E. }\end{array}$ & $\begin{array}{l}\text { Communication in } \\
\text { virtual teams: A } \\
\text { conceptual } \\
\text { framework and } \\
\text { research agenda. }\end{array}$ & 2017 & $\begin{array}{l}\text { Results suggest that communication } \\
\text { plays an important role in predicting } \\
\text { team effectiveness. }\end{array}$ \\
\hline
\end{tabular}

After analyzing all the data, it was evident that the factors that intersect the most is the focus on building trust, effective communication, and performance management. In the next section I will explore each factor in depth by specifically identifying key strategies that support each one of them.

\section{$\underline{\text { Recommendations: }}$}

Trust:

When understanding the effectiveness of virtual teams one factor that tends to receive a lot of attention is trust (Ford et al., 2017). Teams that displayed higher levels of trust were seen to be highly proactive and focused on performance and more positive and willing to provide and receive feedback (Clark et al., 2010). It is also evident that informal workplace interactions and the ability to directly observe others can develop a sense of trust within a team (KasperFuehrera \& Ashkanasy, 2001). Team dispersion and the barriers to communication may therefore pose a threat to the levels of trust among members of a virtual team.

Hence, it is evident that in order to ensure success within virtual teams it is crucial that managers prioritize establishing and developing high levels of trust among team members. Firstly, allocating time to allow team members to socialize and have informal interactions may help develop a sense of trust as it gives team members the opportunity to find similarities among co-workers and create emotional and social connections. This can be done through quick check-ins before virtual meetings or even through the organization of regular virtual social gatherings (Levenson \& McLaughlin, 2020). This may help increase productivity as it will help meet an individual's social needs in the workplace especially during a time that may be challenging and lonely. It is also important to have more frequent and consistent meetings with the team to make up for lost communication thus encouraging transparency and improving levels of trust (Sull et al., 2020). Consistent socialization practices can help develop trust among virtual teams, however they may not be sufficient to sustain it in situations where conflict may arise among team members (Kanawattanachai \& Yoo, 2002). Hence, it is crucial that managers reevaluate their conflict prevention strategies to prevent a loss in levels of trust (Kanawattanachai \& Yoo, 2002). The frequent use of emails from team members can prevent the rise of conflict as it increases transparency (Griffith et al., 2002). This is due to the fact that rapid e-mail responses may act as an alternative to quick conversations and replicate the transfer of knowledge that would've taken place in a physical office thus preventing damage to the levels of trust. Data collected also suggests that virtual teams that frequently utilize technologybased forms of communication are found to experience lower levels of task, relational and process conflict (Wakefield et al., 2008). Therefore, encouraging and providing team members with the technological resources to have frequent communication is crucial to prevent conflict and maintain high levels of trust. 


\section{Communication:}

Most of the issues that arise within virtual teams are caused by barriers that result in poor communication. Communication among virtual team members is frequently less regular and tends to be less effective than in-person interaction, as it often lacks a significant number of contextual cues and information about emotional states (Watkins, 2013). With the rapid development in technology and the ability to consistently stay connected it is easy to assume that virtual teams may experience effective communication, however a team's performance strongly depends not on the resources provided but on how people use the various technological tools offered (Hill \& Bartol, 2018). In the previous section, I highlighted how methods and the quality of communication among team members virtually can have a huge impact on the overall levels of trust which in turn can influence overall team performance and success. It is therefore crucial that managers allocate time and resources in order to identify various technological tools that best fit with the task and the team dynamic (Hill \& Bartol, 2018) and invest in them (Watkins, 2013). After identifying the right technological tools that contribute to effective team communication, the next steps would be to set communication expectations. Creating a team charter will help establish and emphasize the social norms and behavioral expectations when taking part in virtual meetings as well as the rules on which mode of communication to use when (Watkins, 2013). It is important to ensure that the charter covers the various aspects of communication such as, frequency, quality, and timeliness to ensure that overall team performance is not compromised (Marlow et al., 2017).

As mentioned in the previous section it is also vital to create a space and provide the resources for interpersonal and informal communication. This may be of top priority due to the pandemic and the impacts that may have on the mental health and performance. This need places an emphasis on consistently scheduling 1:1 check in with team members in order to create a safe space to provide and receive feedback, encouraging transparency, and developing trust (Watkins, 2013).

Overall, the process of finding the right tools and methods of communication is going to be unique for each team. Finding the best methods may be a time consuming and expensive process; however, it is evident that effective communication has a positive effect on the overall team performance and morale making it a priority (Lurey \& Raisinghani, 2001).

\section{Performance and Task Management:}

The massive growth in communication technologies and innovative management tools, processes and techniques has permitted geographically dispersed teams to operate and perform in a virtual setting (Shopee \& Marnewick, 2016). When managing teams that have transitioned to the virtual space due to the pandemic, managers may need to reevaluate their performance and task management systems to better cater to their team's needs.

Firstly, due to the distance and barriers to regular communication that is associated with virtual teams, managers may need to identify leadership skills that each member may possess and assign more leadership roles to them (Newman \& Ford, 2020). Shared leadership can be described as a cooperative leadership process, whereby numerous team members take the lead to engage in team leadership functions (Hoch \& Dulebohn, 2017). Shared leadership has seen improve levels of satisfaction, trust, and autonomy which in turn positively impact the overall 
performance of the team (Robert \& You, 2018). This will also result in various teams widening the overall decision-making circle allowing managers to expand their capacity, gain new perspective, and encourage transparency and trust among team members (Levenson \& McLaughlin, 2020).

Another important performance management aspect of virtual teams is the emphasis on quality goal setting. Establishing goals with high levels of quality and investing in developing commitment towards those goals can have a positive impact on the performance of virtual teams (Forester et al., 2007). Effective goal setting structures can also better support virtual teams by improving levels of cohesion and commitment therefore creating a climate that fosters collaboration making the team better equipped for decision making (Huang et al., 2003).

Finally, a key aspect of performance management that can contribute to increases in overall team performance is feedback. Provision of consistent, constructive, and relevant feedback encourages communication and collaboration among team members (Geister et al., 2006). It is crucial that virtual team leaders identify the right forms of feedback for their particular team, whether it be team or individual feedback, and use the right technological tools in order to ensure effectiveness (Hertel et al., 2005).

\section{Conclusion:}

The purpose of this paper was to identify ways to improve the performance of virtual teams through the analysis of existing literature and create a resource to support current leaders and managers as they navigate virtual teams. Based on all the data I have collected and studied on virtual teams and the barriers they may face, I have identified three areas that must be a priority to organizations: trust, communication, and performance and task management.

Some of the limitations to this study may be the lack of empirical data that exists on virtual teams that have been created primarily due to this pandemic. My approach to avoid inaccuracies that may be a result of this as well as to bridge the gap in existing literature was to identify whether the solutions were relevant based on data that exists surrounding the experiences of current employees. Nevertheless, this study highlights a need for future research, primarily empirical research on this topic.

\section{$\underline{\text { References: }}$}

Ale Ebrahim, N., Ahmed, S., \& Taha, Z. (2009). Virtual Teams: A Literature Review (SSRN Scholarly Paper ID 1501443). Social Science Research Network. https://papers.ssrn.com/abstract $=1501443$

Alec Levenson, \& Patrick McLaughlin. (2020). New Leadership Challenges for the Virtual World of Work. https://sloanreview.mit.edu/article/new-leadership-challenges-for-the-virtual-world-ofwork/ 
Anthony M. Townsend, Samuel M. DeMarie, \& Anthony R. Hendrickson. (1998). Virtual teams: Technology and the workplace of the future $\mid$ Academy of Management Perspectives. https://journals.aom.org/doi/abs/10.5465/ame.1998.1109047

Atreyi Kankanhalli, Bernard C.Y. Tan, \& Kwok-Kee Wei. (2014). Conflict and Performance in Global Virtual Teams: Journal of Management Information Systems: Vol 23, No 3. https://www.tandfonline.com/doi/abs/10.2753/MIS07421222230309? casa token=pUiO9TN6kJsAAAAA:a78NEGV00PSTt4iCZ_k99D0wWGeaDjZle AZ21zjHEcLH9e1TOauRjKCwe6pgIYqNrDHEHaNKoWA

Brynjolfsson, E., Horton, J., Ozimek, A., Rock, D., Sharma, G., \& TuYe, H.-Y. (2020). COVID-19 and Remote Work: An Early Look at US Data (No. w27344; p. w27344). National Bureau of Economic Research. https://doi.org/10.3386/w27344

Clark, W. R., Clark, L. A., \& Crossley, K. (2010). Developing Multidimensional Trust Without Touch In Virtual Teams. 17.

Donald Sull, Charles Sull, \& Josh Bersin. (2020). Five Ways Leaders Can Support Remote Work. https://sloanreview.mit.edu/article/five-ways-leaders-can-support-remote-work/

Dube Shopee \& Marnewick Carl. (2016). A conceptual model to improve performance in virtual teams: Original research. South African Journal of Information Management, 18(1), 1-10. https://doi.org/10.4102/sajim.v18i1.674

Eva C. Kasper-Fuehrera \& Neal M. Ashkanasy. (2001). Communicating trustworthiness and building trust in interorganizational virtual organizations. https://journals.sagepub.com/doi/abs/10.1177/014920630102700302?casa_token=7R_6osc94W YAAAAA:PRpmHoYO93sLYyKWokvowzJeLsxOgx8qIuviAatgnAEKH60TPyHothAD7JtJ81 nzcgTo5RHRtrw

Ford, R. C., Piccolo, R. F., \& Ford, L. R. (2017). Strategies for building effective virtual teams: Trust is key. Business Horizons, 60(1), 25-34. https://doi.org/10.1016/j.bushor.2016.08.009

Forester, G. L., Thorns, P., \& Pinto, J. K. (2007). Importance of Goal Setting in Virtual Project Teams. Psychological Reports, 100(1), 270-274. https://doi.org/10.2466/pr0.100.1.270-274 
Frank Siebdrat, Martin Hoegl, \& Holger Ernst. (2009, July 1). How to Manage Virtual Teams. https://sloanreview.mit.edu/article/how-to-manage-virtual-teams/

Griffith, T. L., Mannix, E. A., \& Neale, M. A. (2002). Conflict and Virtual Teams. 32.

Hertel, G., Geister, S., \& Konradt, U. (2005). Managing virtual teams: A review of current empirical research. Human Resource Management Review, 15(1), 69-95. https://doi.org/10.1016/j.hrmr.2005.01.002

Hill, N. S., \& Bartol, K. M. (2018). Five Ways to Improve Communication in Virtual Teams. MIT SLOAN MANAGEMENT REVIEW, 7.

Hoch, J. E., \& Dulebohn, J. H. (2017). Team personality composition, emergent leadership and shared leadership in virtual teams: A theoretical framework. Human Resource Management Review, 27(4), 678-693. https://doi.org/10.1016/j.hrmr.2016.12.012

Huang, W. W., Wei, K.-K., Watson, R. T., \& Tan, B. C. Y. (2003). Supporting virtual team-building with a GSS: An empirical investigation. Decision Support Systems, 34(4), 359-367. https://doi.org/10.1016/S0167-9236(02)00009-X

Kanawattanachai, P., \& Yoo, Y. (2002). Dynamic nature of trust in virtual teams. The Journal of Strategic Information Systems, 11(3), 187-213. https://doi.org/10.1016/S0963-8687(02)00019-7

Marlow, S. L., Lacerenza, C. N., \& Salas, E. (2017). Communication in virtual teams: A conceptual framework and research agenda. Human Resource Management Review, 27(4), 575-589. https://doi.org/10.1016/j.hrmr.2016.12.005

Martins, L. L., Gilson, L. L., \& Maynard, M. T. (2004). Virtual Teams: What Do We Know and Where Do We Go From Here? Journal of Management, 30(6), 805-835. https://doi.org/10.1016/j.jm.2004.05.002

Michael D. Watkins. (2013). Making Virtual Teams Work: Ten Basic Principles. Harvard Business Review. https://hbr.org/2013/06/making-virtual-teams-work-ten 
Myers, P. A. W. and J. (2020, March 31). The federal government's coronavirus actions and failures. Brookings. https://www.brookings.edu/research/the-federal-governments-coronavirus-actionsand-failures-timeline-and-themes/

Newman, S. A., \& Ford, R. C. (2020). Five Steps to Leading Your Team in the Virtual COVID-19 Workplace. Organizational Dynamics, 100802. https://doi.org/10.1016/j.orgdyn.2020.100802

Powell, A., Piccoli, G., \& Ives, B. (2004). Virtual teams: A review of current literature and directions for future research. ACM SIGMIS Database: The DATABASE for Advances in Information Systems, 35(1), 6-36. https://doi.org/10.1145/968464.968467

Robert, L. P., \& You, S. (2018). Are you satisfied yet? Shared leadership, individual trust, autonomy, and satisfaction in virtual teams. Journal of the Association for Information Science and Technology, 69(4), 503-513. https://doi.org/10.1002/asi.23983

Shachaf, P. (2008). Cultural diversity and information and communication technology impacts on global virtual teams: An exploratory study. Information \& Management, 45(2), 131-142. https://doi.org/10.1016/j.im.2007.12.003

Susanne Geister, Udo Konradt, \& Guido Hertel. (2006). Effects of Process Feedback on Motivation, Satisfaction, and Performance in Virtual Teams. https://journals.sagepub.com/doi/abs/10.1177/1046496406292337?casa_token=mvonAMmBgu 8AAAAA:wE1PgfWnNOnU4LGftWJ-zmtqex4i2fQIIIyAWofwRdH1QJv7oARrjXIW1WXnGxbSJjWs9SwTCo

Townsend, A. M., DeMarie, S. M., \& Hendrickson, A. R. (1998). Virtual teams: Technology and the workplace of the future. Academy of Management Perspectives, 12(3), 17-29. https://doi.org/10.5465/ame.1998.1109047

Virginia Brandt, William England, \& Susan Ward. (2011). Virtual Teams. https://search.proquest.com/openview/bdf30c17bb9dbb9d2501b91f76536531/1?pqorigsite $=$ gscholar \&cbl $=37905$

Wakefield, R. L., Leidner, D. E., \& Garrison, G. (2008). Research Note-A Model of Conflict, Leadership, and Performance in Virtual Teams. Information Systems Research, 19(4), 434-455. https://doi.org/10.1287/isre.1070.0149 
Wong, M. (2020, June 29). A snapshot of a new working-from-home economy. Stanford News. https://news.stanford.edu/2020/06/29/snapshot-new-working-home-economy/

Wong, S.-S., \& Burton, R. M. (2000). Virtual Teams: What are their Characteristics, and Impact on Team Performance? Computational \& Mathematical Organization Theory, 6(4), 339-360. https://doi.org/10.1023/A:1009654229352

Lurey, J. S., \& Raisinghani, M. S. (2001). An empirical study of best practices in virtual teams. Information \& Management, 38(8), 523-544. https://doi.org/10.1016/S0378-7206(01)00074-X 